\title{
KNOWLEDGE ABOUT RABIES AND LEISHMANIASIS IN STUDENTS OF PUBLIC SCHOOLS IN THE MUNICIPALITIES OF APODI, FELIPE GUERRA AND SEVERIANO MELO IN RIO GRANDE DO NORTE, BRAZIL
}

\author{
F. R. C. MOREIRA'*, P. V. S. Q. MOREIRA², F. L. M. OLIVEIRA', N. R. L. MORAIS', J. C. SOUZA', J. K. GÓIS', V. E. H. \\ GURGEL $^{1}$, L. M. O. COSTA ${ }^{1}$ and G. B. MELO JÚNIOR ${ }^{1}$ \\ ${ }^{1}$ Instituto Federal de Educação, Ciência e Tecnologia do Rio Grande do Norte \\ ${ }^{2}$ Universidade Estadual do Rio Grande do Norte - UERN \\ faviano.moreira@ifrn.edu.br
}

Article received in July/2014 and accepted in January/2016

DOI: $10.15628 /$ holos.2016.2244

\section{ABSTRACT}

This objective of this work was to assess the knowledge of students in public schools about rabies and leishmaniasis, through educational interventions. A total of 628 questionnaires were applied in public students from Apodi, Felipe Guerra and Severiano Melo. The questionnaires were administered before and after the educational interventions in the form of lectures. The data were discussed through a descriptive analysis. Before the presentation, $53.9 \%$ of students claimed to know the transmission mode of leishmaniasis and after, this percentage increased to $92.2 \%$. However, before the lectures, only $6.0 \%$ of respondents associated the transmission to sandflies, and after, this percentage
\end{abstract}

increased to $75.7 \%$. For rabies, before the lectures, $63.7 \%$ of students reported knowing how rabies is transmitted and, after the lectures, $92.8 \%$ said how it was the transmission. Concerning the transmission, before the presentations, $68.3 \%$ reported that it was through bite or injury of animals and, after the lectures, the index increased to $80.4 \%$. In conclusion, the student's perception of public education on rabies and leishmaniasis was higher in all aspects addressed after educational intervention compared to the same questions about the knowledge of the disease before the intervention. It also concludes that the perception of students for rabies is greater than for leishmaniasis.

KEYWORDS: education, school, extension, public health, zoonoses.

\section{CONHECIMENTO SOBRE A RAIVA E A LEISHMANIOSE EM ALUNOS DE ESCOLAS PÚBLICAS NOS MUNICÍPIOS DE APODI, FELIPE GUERRA E SEVERIANO MELO NO RIO GRANDE DO NORTE}

\section{RESUMO}

O objetivo do trabalho foi avaliar o conhecimento de alunos da rede pública de ensino sobre a raiva e a leishmaniose, através de intervenções educativas. Foram aplicados 628 questionários para alunos de escolas públicas de Apodi, Felipe Guerra e Severiano Melo. Os questionários foram aplicados antes e após as intervenções educativas na forma de palestras. Os dados foram discutidos através de uma análise descritiva. Antes das palestras $53,9 \%$ dos alunos afirmaram conhecer a forma de transmissão da Leishmaniose e após, esse percentual passou para $92,2 \%$. Todavia, antes das palestras somente $6,0 \%$ dos entrevistados associaram a transmissão ao mosquito e após, esse percentual passou para $75,7 \%$. Para a Raiva, $63,7 \%$ dos alunos afirmaram saber, antes das palestras, como a Raiva se transmite e após as palestras $92,8 \%$ disseram saber como era a transmissão. Quanto à forma de contágio, antes das palestras, $68,3 \%$ informaram que era através de mordida ou ferimento de animais e após as palestras o índice aumentou para $80,4 \%$. Como conclusão, a percepção dos alunos da rede pública de ensino sobre raiva $\mathrm{e}$ leishmaniose foi maior em todos os aspectos abordados após a intervenção educativa, quando comparada aos mesmos questionamentos sobre o conhecimento das doenças antes da intervenção. Conclui-se também que a percepção dos estudantes para a raiva é maior do que para a leishmaniose.

PALAVRAS-CHAVE: educação, escolas, extensão, saúde pública, zoonoses. 


\section{INTRODUCTION}

Despite the disagreement about the word, it is known that zoonoses have plagued populations throughout history, generating huge social losses. Many of them believed to be endemic diseases, dispersed on millions of people over the centuries and have been capable of resisting to modernity, as in the case of rabies and leishmaniasis (RIBEIRO, 2010).

Rabies is an anthropozoonosis transmitted to human by the inoculation of the virus contained in the saliva of infected animals, primarily through bites and, more rarely, by scratch and licking of mucous membranes. Although being known since antiquity, it remains currently a serious public health problem in developing countries and produces high economic losses to livestock (BRASIL, 2005).

It is an acute encephalitis, which leads the victims to death in practically $100 \%$ of the cases, being one of the oldest known diseases. It presents four transmission cycles: urban, rural, aerial, and wild. In the urban cycle, the main sources of infection are the dog and the cat. In Brazil, the bat is primarily responsible for maintaining the wild chain, but other shells like monkey and fox also participate of the transmission (BRASIL, 2005 and 2008). The common vampire bat (Desmodus rotundus) is the main disease agent to domestic herbivores, such as cattle, horses, goats, sheep and pigs, because these are the most common food source, representing the rural cycle, although these animals can also be infected by the aggression of dogs, cats and wild rabid mammals. The aerial cycle is important in the virus maintenance among the diverse bat species, which spread this viral agent, because they surpass geographical barriers, insofar as they are the only flying mammals (GOMES et al., 2012).

Rabies is present in Rio Grande do Norte (RN, BRAZIL), because in 2010 one case of human rabies transmitted by bat was notified in the municipality of Frutuoso Gomes. Between 2007 and 2010, in the urban cycle (domestic dogs and cats), 6 cases in dogs and cats were reported, being the ninth state with more record of cases in this cycle in Brazil. Compared to other transmission cycles, 41 cases of rabies have been reported in rural cycle (farm animals), 60 in aerial cycle (bats) and 14 in wild cycle (wild dogs) (BRASIL, 2011).

Leishmaniasis are zoonotic diseases that affect humans, domestic and wild animals, and it is currently undergoing substantial geographical expansion. The infection is caused by protozoan of the family Trypanosomatidae and genus Leishmania, and the parasite transmitted by insects of the family Psychodidae and subfamily Phlebotominae. The transmission occurs through the bite of infected transmitter insects, without person-to-person or animal-to-animal transmission described in Brazil. It represents a number of different diseases, which can compromise skin, mucous membranes and viscera, depending on the parasite species and the host's immune response (ARRUDA, 2010).

It is estimated that the cutaneous (CL), mucosal (ML) and visceral (VL) leishmaniasis show a prevalence of 12 million cases in the world, distributed in 98 countries, in four continents (Americas, Europe, Africa and Asia) (OMS, 2013; ARRUDA, 2010). In the Northeast region, the VL is presented, for many years, in the endemic form, especially in the States of Ceará, Bahia, Maranhão, Piauí, Pernambuco and Rio Grande do Norte. In all States, there is an association of VL with the presence of infected dogs and plenty of vector Lutzomyia longipalpis (XIMENES et al., 2000). In Rio 
Grande do Norte, besides the increased incidence, there has been expansion of the disease. Of the 162 municipalities in the State, 140 have submitted case reports of VL between 1986 and 2011 (JERONIMO et al., 1994; SINAN, 2011).

The problems related to animal health and, consequently, public health can be minimized when it is applied education in health. To ensure a healthy human-animal relationship, it is necessary to educate people, not simply with advertisements and announcements in mass media, but also with systematic programs of education in health, properly directed to the target audience (BALTAZAR et al., 2004).

Thus, the objective of this work is to evaluate the perception of the public school students about the rabies and leishmaniasis, before and after educational intervention.

\section{MATERIAL AND METHODS}

The work was developed in 12 Municipal (M.S.), State (S.S.) and Federal schools. In Apodi, the M.S. were covered Lourdes Mota, M.S. Lindaura Silva, M.S. Francisco Targino da Costa, S.S. Professor Antonio Dantas, S.S. Professor Gerson Lopes, S.S. Zenilda Gama and the Federal Institute of education, science and technology of the RN - IFRN. In Felipe Guerra, the M.S. were Jose do Patrocínio Barra and S.S. Antonio Francisco and in Severiano Melo, the M.S. were Ricardo Sérgio, S.S. Severiano Melo and S.S. Américo Holanda.

The studied population was composed of students between the 5th and the 9th year of elementary school and the 1st and 3rd year of high school in integrated and young and adult education (EJA). In each of the surveyed schools, it was defined a percentage of $10 \%$ of students who would respond to the questionnaires by following a random methodology. A total of 628 questionnaires were applied. Participated in this study students aged from 10 to 19 years in elementary school and between the ages 14 and 61 years, from both sexes and in the period from July to December 2011.

The questionnaires were developed with open and closed questions (ALMEIDA FILHO and ROUQUAYROL, 2002), containing information about the concept of zoonosis, rabies and leishmaniasis transmission, presence of bats in students' residences and way to combat them, such as the following:

- Do you know how to get the Calazar?

- Do you know how to catch the rabies?

- Can bats transmit rabies to humans?

- There are bats in your house?

- If Yes, how do you fight them?

As a form of education in health, lectures were carried out using simple and accessible language, with multimedia resources - slide show with diagrams, illustrations and concepts within the proposed theme, where the same lasted, on average, 40 minutes. The themes were: Rabies and leishmaniasis, with emphasis on the concepts of zoonoses and the outlines of the cycle, transmission, clinical signs of the disease and prevention.

The questionnaires applied before the lectures were delivered to students in order to be answered during the classes, in space given by the teachers. The questionnaires applied after the 
lectures were applied thereupon the same, as a parameter to evaluate the content assimilation (AMARAL et al., 2009).

The data was tabulated in Excel worksheet and the descriptive analysis was performed, and the results were presented in percentages.

\section{RESULTS}

The results referring the students' perception about the leishmaniasis are presented in Table 1. In the same can be observed that there was an increase of $37 \%$ in the response assimilation due to the fact of knowing how the calazar is transmitted. However, the most representative data were in the answers front of the question about the leishmaniasis transmission, because before the lectures only $5.6 \%$ stated that it was through the sandfly, and after the lectures this index increased to $75.7 \%$.

Table 1 - Knowledge of leishmaniasis transmission form for students of public schools in the municipalities of Apodi, Felipe Guerra and Severiano Melo in RN, before and after the educational intervention $(n=628)$

\begin{tabular}{|c|c|c|c|}
\hline \multirow{2}{*}{ Moments } & \multicolumn{3}{|c|}{ Do you know how to get the Calazar? } \\
\hline & Yes & No & Not responded \\
\hline Before interventions & $55.2 \%$ & $44.3 \%$ & $0.5 \%$ \\
\hline After interventions & $92.2 \%$ & $7.8 \%$ & $0.0 \%$ \\
\hline \multirow{2}{*}{$\begin{array}{l}\text { Forms of transmission mentioned by } \\
\text { respondents }\end{array}$} & \multicolumn{3}{|c|}{ If Yes, how? } \\
\hline & Befor & tions & After interventions \\
\hline Sandfly & & & $75.7 \%$ \\
\hline Interaction or contact with sick cat or dog & & & $17.3 \%$ \\
\hline injury or bite from sick animal & & & $3.0 \%$ \\
\hline Feces or urine or hair of animals & & & $2.5 \%$ \\
\hline Walking barefoot & & & $1.7 \%$ \\
\hline Don't know or don't answered & & & $1.5 \%$ \\
\hline
\end{tabular}

This result highlights the precariousness of information about $V L$ among survey respondents and corroborate with the results of Lobo et al (2013) in Caxias-MA, where there was an increase of $52.4 \%$ among students who stated that the bite of the insect vector was the main transmission form of the VL after lecture on the topic. The data found in the research from Maranhão (LOBO et al., 2013), Minas Gerais (BORGES et al., 2008 and FRANÇA et al., 2013) and São Paulo (GENARI et al., 2012) corroborate the results obtained in Apodi-RN, with respect to the low knowledge level of the disease.

As well as other diseases, the knowledge about leishmaniasis is generally restricted to individuals who have experienced the disease or have had relatives or neighbors with the disease (UCHOA et al., 2004). A survey performed with teachers of basic education in the disciplines of biology and sciences about leishmaniasis demonstrated that they attach little importance to leishmaniasis, discuss the contents superficially together with the students because consider themselves unprepared (FRANÇA et al., 2013).

This reality notes that the clarification of the population becomes essential as auxiliary tool in the control of leishmaniasis and that, in order to gain control of VL in domestic environment, it is necessary to provide extensive information about the disease, aiming to increase the security in the domestic space (DOBLES-ULLOA \& PERRIARD, 1994). In this sense, the education in health to 
the community is highlighted, with reference to the main circulating diseases, aiming an improvement in the life quality of the population (RAMOS, 2011).

The educational practices in different fronts, which can count on the participation of doctors and veterinarians during their consultations, health agents during home visits, and teachers and children informed that can act as diffusers of the subject in their homes and communities, being able to act significantly in the control of endemic diseases (UCHOA et al., 2004).

In Table 2, the results are displayed in the face of the students' perception about the rabies transmission, where it can be observed that there has been an increase of $28.7 \%$ in the statement of rabies transmission. Specifically for the transmission form, before the lectures, $68.9 \%$ said that the bites and injuries of positive animals were the main cause of rabies and, after the lectures, the index reached $80.4 \%$.

Table 2 - Knowledge of rabies transmission form for students of public schools in the municipalities of Apodi, Felipe Guerra and Severiano Melo in RN, before and after the application of educational interventions $(n=628)$

\begin{tabular}{|c|c|c|c|}
\hline \multirow{2}{*}{ Moments } & \multicolumn{3}{|c|}{ Do you know how to catch the rabies? } \\
\hline & Yes & No & Not responded \\
\hline Before interventions & $64.1 \%$ & $35.9 \%$ & $0.0 \%$ \\
\hline After interventions & $92.8 \%$ & $7.2 \%$ & $0.0 \%$ \\
\hline \multirow{2}{*}{$\begin{array}{c}\text { Forms of transmission } \\
\text { mentioned by respondents }\end{array}$} & \multicolumn{3}{|c|}{ If Yes, how? } \\
\hline & \multicolumn{2}{|c|}{ Before the lectures } & After the lectures \\
\hline Bite or injury by positive animal & \multicolumn{2}{|c|}{$68.9 \%$} & $80.4 \%$ \\
\hline Contact with sick animals & \multicolumn{2}{|c|}{$18.2 \%$} & $12.9 \%$ \\
\hline Not responded & \multicolumn{2}{|c|}{$9.3 \%$} & $1.5 \%$ \\
\hline Other ${ }^{1}$ & \multicolumn{2}{|c|}{$3.6 \%$} & $5.2 \%$ \\
\hline
\end{tabular}

1: Sandfly, walking barefoot, animal hair, etc.

In the face of the obtained result, it was verified that the population has a knowledge level about rabies higher than leishmaniasis. It is believed that this fact is probably due to the antirabic vaccination campaigns that occur annually in the country. However, not all individuals recognize it as a disease transmissible from animals to humans or vice versa (LIMA et al., 2010; LAGES, 2009).

The increasing proximity between the human population and the domestic animal nowadays, with the existence of new ties between animals and their owners, situations that probably occur as reflections of modern life, can increase the transmission risk of zoonoses, including the rabies (DIAS et al., 2012). Furthermore, the works that discuss about the prevention of rabies, mostly involve technical measures such as animal vaccination, capture for control of wild mammals and pre- and post-exposure prophylaxis for human, besides the effective and appropriate epidemiological surveillance. Generally, the works of education in health are minimized in control programs (GOMES et al., 2012; JESUS and GOMES, 2012).

Whereas the profile of people battered by dogs is male student, under 14 years and resident in urban area of low risk for human rabies transmitted by dogs (RAMOS, 1978; ROLIM et al., 2006; OLIVEIRA et al., 2012), it is relevant that educational practices with school-aged young people are performed aiming a greater knowledge about the disease risks and their prevention forms. 
In Table 3 are the information about the presence of bats in the students' homes and the way to combat them. Of the students who participated in the research, $71.7 \%$ associated bats with rabies at first, and after the realization of educational activity, $91 \%$ were able to accomplish this association of bats as transmitters of rabies virus.

Table 3 - Knowledge about the participation of the bats in the transmission cycle of rabies, its presence and main ways to combat in the students' homes from public schools in the municipalities of Apodi, Felipe Guerra and Severiano Melo in RN, before and after the application of educational interventions $(n=628)$

\begin{tabular}{|c|c|c|c|}
\hline \multirow{2}{*}{ Moments } & \multicolumn{3}{|c|}{ Can bats transmit rabies? } \\
\hline & Yes & No & Not responded \\
\hline Before interventions & $71.7 \%$ & $27.3 \%$ & $1.0 \%$ \\
\hline \multirow[t]{2}{*}{ After interventions } & $91.0 \%$ & $9.0 \%$ & $0.0 \%$ \\
\hline & \multicolumn{3}{|c|}{ There are bats in your house? } \\
\hline Yes & \multicolumn{3}{|c|}{$15.9 \%$} \\
\hline No & \multicolumn{3}{|c|}{$84.1 \%$} \\
\hline \multicolumn{4}{|c|}{ If Yes, how do you fight them? } \\
\hline Using poison & \multicolumn{3}{|c|}{$26.9 \%$} \\
\hline Killing the bat & \multicolumn{3}{|c|}{$23.9 \%$} \\
\hline Making nothing & \multicolumn{3}{|c|}{$16.4 \%$} \\
\hline Not responded & \multicolumn{3}{|c|}{$11.9 \%$} \\
\hline Moving the bat away & \multicolumn{3}{|c|}{$10.4 \%$} \\
\hline Other ${ }^{1}$ & \multicolumn{3}{|c|}{$10.4 \%$} \\
\hline
\end{tabular}

1: Illuminating the environment, hot water, capturing the animal and destroying the burrow

The perception indices regarding this relation bat-rabies are variables (SILVA et al., 2013; LAGES, 2009; RANUCCl et al., 2014) and may be related to the age group of the survey respondents, bearing in mind that in Apodi-RN, where the present study was conducted, survey respondents were older school-aged students.

With regard to visualization of bats, these flying mammals are present in $15.9 \%$ of residences, information similar to that found in Mato Grosso, where the houses were places where more animals were observed (SILVA et al., 2013). The possible entry of bats in homes and the permanence of those in shelters on the roofs can be caused by several factors, such as the demand for fruit or sweet solution offered to hummingbirds, proximity of daytime shelters or fruiting trees (ESBÉRARD et al., 1994). Although bats have before the society a hostile image, these animals are important in the seed spreading, insect control and flower pollination (RANUCCl et al., 2014).

Regarding the way to combat, the main cited in this study were using poisons (25.8\%), killing the animals (24.2\%) and moving them away (10.6\%); $16.7 \%$ said making nothing and $12.1 \%$ did not know or did not respond. It is important to note that the method of killing the animals, one of the most cited in the present research in schools from Apodi, Felipe Guerra, and Severiano Melo, is not the most appropriate, resulting in contact with the animal and providing contamination with any positive animal for rabies. The correct ways for controlling bats involve monitoring and adaptation of buildings, such as sealing of clearance in roofs, cisterns, space between air conditioner, walls and ceiling. It is also suggested the removal of colonies with meshes, pruning of low tree branches and removal of ripe fruits in plants. For the common vampire bats, the use of light and mechanical barriers as fine meshes and use of poisons. It is highlighted that all methods must be guided by qualified professional (BREDT, 1998). 
Finally, the presence of bats in environments for human use is indicative of risk, especially when they are children or patients with delayed mental development (SOUZA et al., 2005), and should be a control of chiropters, especially the common vampire bats, in order to decrease the circulation of rabies virus and, consequently, the occurrence chances of human rabies, especially in the rural area, since bats of any species are considered animals at high risk of rabies transmission, once the virus transmission can occur through small or even undetectable lesions (COSTA et al., 2000).

In the face of the obtained results, it is emphasized the need to carry out continued educational work in the studied areas in Apodi, Felipe Guerra, and Severiano Melo, considering that education is the most effective way to inform, change habits and transform people into knowledge spreaders and active vigilant (ZETUN, 2009). Knowledge and education comprise, therefore, the basis of any program of prevention, control and eradication of diseases.

\section{CONCLUSIONS}

The perception of the public school students about rabies and leishmaniasis was higher in all addressed aspects after the educational intervention, when compared to the same questions about the knowledge of diseases before the educational intervention. It is concluded that the perception of students for rabies is higher than for leishmaniasis. The conducted diagnosis can be the basis for schools and the municipal departments of health and education to perform continuous awareness work of students about leishmaniasis and rabies, as well as the other endemic diseases found in the region.

\section{REFERENCES}

1. ALMEIDA FILHO, N.; ROUQUAYROL, M. Z. Introdução à epidemiologia. 3. ed. Rio de Janeiro: MEDSI, 2002, 293 p.

2. AMARAL, C.H; et al. Conceito de Zoonoses em Alunos de Ensino Básico de Piraquara, Área de Proteção Ambiental da Região Metropolitana de Curitiba. In: IV Congresso Latino Americano, $X$ Congresso Brasileiro de Higienistas de Alimentos, III Encontro de Centros de Controle de Zoonoses e II Encontro do Sistema Brasileiro de Inspeção de Produtos de Origem Animal., 2009, Florianopólis. Anais.... Revista Higiene Alimentar. São Paulo : DPI Estudio e Editora Ltda., 2009. v. 23. p. 476-477.

3. ARRUDA, M.M. Leishmanioses. In: Manual de Zoonoses. Programa de Zoonoses região Sul, v. 1, 2a ed., p.68-90, 2010.

4. BALTAZAR, C., et al. Formação de multiplicadores na área de saúde pública e higiene de alimentos. Revista Ciência em Extensão, v.1, n.1, p.79, 2004.

5. BORGES, B.K.A.; et al. Avaliação do nível de conhecimento e de atitudes preventivas da população sobre a leishmaniose visceral em Belo Horizonte, Minas Gerais, Brasil. Cad. Saúde Pública, Rio de Janeiro, v.4, n. 24, p.777-784, 2008.

6. BRASIL. Ministério da Saúde. Vigilância Epidemiológica, 2011. Sistema nacional de vigilância em saúde: relatório de situação: Rio Grande do Norte - 5. ed. - Brasília:Ministério da Saúde, $35 \mathrm{p}$. 
7. BRASIL. Ministério da Saúde. Secretaria de Vigilância em Saúde. Departamento de Vigilância Epidemiológica. Manual de Diagnostico Laboratorial da Raiva. Brasília: Editora do Ministério da Saúde, 2008. 108 p.

8. BRASIL. Ministério da Saúde. Secretaria de Vigilância em Saúde. Guia de vigilância epidemiológica, 6. ed. Brasília, 2005. 816 p.

9. BREDT, A.; et al. Manual de manejo e controle de morcegos em áreas urbanas e rurais. Brasília: Fundação Nacional de Saúde. 117 p., 1998.

10. COSTA, W.A.; et al. Profilaxia da raiva humana. 2a Ed. São Paulo, Instituto Pasteur, 2000 (Manuais, 4) 33p.

11. DIAS, I. C. L. GUIMARÃES, C. A.; MARTINS, D. F.; BRANDÃO, V. M.; SILVA, I. A. da; SILVA, M. I. S. Zoonoses e posse responsável: percepção e atitudes entre crianças do ensino fundamental. Revista Ciência em Extensão, v.8, n.2, p.75, 2012.

12. DOBLES-ULLOA A, PERRIARD C. Representaciones, actitudes y practicas respecto a la leishmaniasis cutánea en la población del Cantón de Acosta, Provincia de san José, Costa Rioca. Estudio Antropológico exploratório. Cadernos de Saúde Pública, v. 10, n.2, p. 181-189, 1994.

13. ESBÉRARD, C. 1994. Projeto Morcegos Urbanos. Fundação RIOZOO, Manual técnico do Instituto Pasteur, n. 7 - Manejo de quirópteros em áreas urbanas 44p.

14. FRANÇA, V.H.; MARGONARI, C.; SCAHLL, V.T. Percepção de professores do ensino básico em relação as suas práticas educativas sobre leishmanioses: um estudo em área endêmica de Minas Gerais. Revista Ensaio, v. 15, n.3, p.35-51, 2013.

15. GENARI, I.C.C.; PERRI, S.H.V.; PINHEIRO, S.R.; NUNES, C.M. Atividades de educação em saúde sobre leishmaniose visceral para escolares. Veterinária e Zootecnia, v.19, n.1, p.99-107, 2012.

16. GOMES, A.P.; ESPERIDIÃO-ANTONIO, V.; MENDONÇA, B.G.; BENEDITO, H.P.L.; VITORINO, R.R.; PRADO, M.R.M.C.; PRADO JÚNIOR, P.P.; HENRIQUES, B.D.; SANTANA, L.A. Raiva humana. Revista da Sociedade Brasileira de Clínica Médica, v.10, n.4, p.334-340, 2012.

17. JERONIMO, S. M.; OLIVEIRA, R. M.; MACKAY, S.; COSTA, R. M.; SWEET, J.; NASCIMENTO, E. T. et al. An urban outbreak of visceral leishmaniasis in Natal, Brazil. Transactions of the Royal Society of Tropical Medicine and Hygiene, v. 88, n. 4, p. 386-388, 1994.

18. JESUS, A.G.; GOMES, H. Raiva humana: Transmissão a humanos por cães e gatos no município de Balsas-MA - Revista Científica da Faculdade de Balsas, Ano III, n.1, 2012.

19. LAGES, S.L.S. Avaliação da população de cães e gatos com proprietário, e do nível de conhecimento sobre a raiva e posse responsável em duas áreas contrastantes da cidade de Jaboticabal, São Paulo. Dissertação (mestrado) - Universidade Estadual Paulista, Faculdade de Ciências Agrárias e Veterinárias, 2009, 76 p.

20. LOBO, K.S.; BEZERRA, J.M.T.; BRITO, L.M.O.; SILVA, J.S.; PINHEIRO, V.C.S. Conhecimentos de estudantes sobre Leishmaniose Visceral em escolas públicas de Caxias, Maranhão, Brasil. Ciência \& Saúde Coletiva, v.18, n.8, p.2295-2300, 2013.

21. LIMA, A.M.A., ALVES, L.C., FAUSTINO, M.A.G., LIRA, N.M.S. Percepção sobre o conhecimento e profilaxia das zoonoses e posse responsável em pais de alunos do pré-escolar de escolas situadas na comunidade localizada no bairro de Dois Irmãos na cidade do Recife (PE). Ciência \& Saúde Coletiva, v. 15, Supl. 1, p.1457-1464, 2010. 
22. OLIVEIRA, V.M.R.; PEREIRA, P.L.L.; SILVA, J.A.; MIRANDA, C.F.J.; RODRIGUES, K.O.; RODRIGUES, T.O.; MOREIRA, E.C. Mordedura canina e atendimento antirrábico humano em Minas Gerais. Arquivo Brasileiro de Medicina Veterinária e Zootecnia, v.64, n.4, p.891-898, 2012.

23. OMS/WHO. Sustaining the drive to overcome the global impact of Neglected tropical diseases: second who report on neglected tropical diseases, 2013. Disponível em: http://www.who.int/iris/.../1/9789241564540_eng.pdf Acessado em: 11/10/2014.

24. RAMOS, M.C.D. Perfil psicossocial das pessoas agredidas por animais raivosos ou suspeitos de raiva na grande São Paulo. Revista de Saúde Pública, v.12, n.1, p.26.34, 1978.

25. RAMOS, J.V.A. Plano de intervenção para implantação de Ações Educativas de Prevenção e controle da Leishmaniose Tegumentar Americana no Distrito de Três Ladeiras - Igarassu - PE. 2011. Monografia (Especialização em Gestão de Sistemas e Serviços de Saúde) -Departamento de Saúde Coletiva, Centro de Pesquisas Aggeu Magalhães, Fundação Oswaldo Cruz. Recife: 28 f.

26. RANUCCI, L.; JANKE, L.; AGUIAR, E.S.; ORTÊNCIO FILHO, H.; MAGALHÃES JÚNIOR, C.A.O. Concepção de Estudantes Sobre a Importância dos Morcegos no Ambiente. UNOPAR Científica: Ciências Humanas e Educação, v. 15, n. 1, p. 5-10, 2014.

27. RIBEIRO, L.M.L. Análise do conhecimento, sobre leishmaniose visceral e outras zoonoses, de docentes dos três primeiros anos do ensino fundamental em escolas da Região Noroeste de Belo Horizonte, Minas Gerais. Dissertação (mestrado) - Universidade Federal de Minas Gerais, 2010, 113 p.

28. ROLIM, R.L.P.; LOPES, F.M.R.; NAVARRO, I.T. Aspectos da vigilância epidemiológica da raiva no município de Jacarezinho, Paraná, Brasil, 2003. Semina: Ciências Agrárias, v. 27, n. 2, p. 271280, 2006.

29. SILVA, S.G.; MANFRINATO, M.H.V.; ANACLETO, T.C.S. Morcegos: percepção dos alunos do ensino fundamental 30 e 4을 ciclos e práticas de educação ambiental. Ciência \& Educação, v.19, n.4, p. 859-877, 2013.

30. SINAN. Secretaria Municipal de Saúde do Natal/RN. Sistema de Informações de Agravos Notificados. 2.011

31. SOUZA, L.C.; LANGINI, H.; SILVA, R.C.; LUCHEIS, S.B. Vigilância epidemiológica da raiva na região de Botucatu-SP: importância dos quirópteros na manutenção do vírus na natureza. ARS VETERINARIA, v. 21, n. 1, p. 62-68, 2005.

32. UCHOA, C.M.A.; SERRA, C.M.B.; MAGALHÃES, C.M.; SILVA, R.M.M.; FIGLIUOLO, L.P.; LEAL, C.A.; MADEIRA, M.F. Educação em saúde: ensinando sobre a leishmaniose tegumentar americana. Cad. Saúde Pública, Rio de Janeiro, v.20, n.4, p.935-941, 2004.

33. XIMENES, M. F.; CASTELLON, E. G.; DE SOUZA, M. F.; FREITAS, R. A.; PEARSON, R. D.; WILSON, M. E. et al. Distribution of phlebotomine sand flies (Diptera: Psychodidae) in the state of Rio Grande do Norte, Brazil. Journal of Medical Entomology, v. 37, n. 1, p. 162-169, 2000.

34. ZETUN, C.B. Análise quali-quantitativa sobre a percepção da transmissão de zoonoses em Vargem Grande, São Paulo (SP): a importência de companhia, da alimentação e do ambiente. Dissertação (mestrado) - Universidade de São Paulo. Faculdade de Medicina Veterinária e Zootecnia. Departamento de Medicina Veterinária Preventiva e Saúde animal. 2009, $119 f$. 